\title{
EKSTRAKSI MINYAK DARI BIJI ALPUKAT (Persea Americana Mill) MENGGUNAKAN PELARUT N-HEPTANA
}

\author{
Atikah Risyad, Resi Levi Permadani, Siswarni MZ \\ Departemen Teknik Kimia, Fakultas Teknik, \\ Universitas Sumatera Utara, Medan 20155, Indonesia \\ Email: resi.levi.permadani@gmail.com
}

\begin{abstract}
Abstrak
Produksi alpukat yang cukup tinggi di Indonesia menyebabkan limbah biji alpukat meningkat. Biji alpukat memiliki kandungan minyak yang cukup besar sehingga berpotensi untuk dijadikan salah satu sumber minyak nabati. Pelarut yang umum digunakan untuk proses ekstraksi adalah heksana. Namun, heksana ternyata memiliki bahaya yang mengkhawatirkan jika digunakan untuk ekstraksi bahan makanan, sehingga diperlukan pelarut alternatif seperti n-heptana. Penelitian ini dilakukan untuk mengevaluasi pengaruh variabel penelitian pada ekstraksi minyak biji alpukat dengan pelarut nheptana. Metode yang digunakan pada penelitian ini adalah Response Surface Methodology-Central Composite Design (RSM-CCD) dengan memvariasikan waktu ekstraksi, suhu ekstraksi, massa biji alpukat dan volume pelarut $\mathrm{n}$-heptana. Uji ANOVA dengan tingkat kepercayaan $95 \%(\mathrm{p}<0,05)$ menunjukkan bahwa variabel penelitian memberikan pengaruh yang signifikan pada yield minyak biji alpukat yang dihasilkan dengan nilai $\mathrm{R}^{2}=94,24 \%$ pada suhu konstan dan $\mathrm{R}^{2}=93,95 \%$ pada waktu konstan. Karakteristik minyak biji alpukat yang dihasilkan yaitu berwarna oranye, densitas $0,71 \mathrm{~g} / \mathrm{ml}$, viskositas $0,43 \mathrm{cP}$, dan FFA 2,76\%. Analisis komposisi asam lemak minyak biji alpukat diperoleh komponen asam lemak yang dominan adalah asam lemak tidak jenuh jamak yaitu asam linoleat sebesar $47,3531 \%$ (b/b), asam lemak jenuh berupa asam palmitat sebesar 20,3439\% (b/b), dan asam lemak tidak jenuh tunggal yaitu asam oleat sebesar 15,8823\% (b/b).
\end{abstract}

Kata kunci: alpukat, asam linoleat, ekstraksi, heptana, minyak biji alpukat

\begin{abstract}
Avocado production is quite high in Indonesia led to increased waste avocado seed. Avocado seeds have an oil content large enough to potentially be used as a source of vegetable oil. A commonly used solvent for the extraction process is hexane. However, hexane proved to have an alarming danger if it is used for the extraction of food ingredients, necessitating alternative solvents such as n-heptane. This study was conducted to evaluate the effect of variable research on avocado seed oil extraction using n-heptane. The method used in this study is Response Surface Methodology-Central Composite Design (RSM-CCD) by varying the time of extraction, extraction temperature, avocado seed mass and volume of the solvent $n$-heptane. ANOVA with $95 \%$ confidence level $(p<0.05)$ showed that the variables have a significant influence on the yield of avocado seed oil produced by the value of $R^{2}=$ $94.24 \%$ at constant temperature and $R^{2}=93.95 \%$ at constant time. Characteristics of avocado seed oil is a orange color, density amounted to $0.71 \mathrm{~g} / \mathrm{ml}$, viscosity amounted to $0.43 \mathrm{cP}$, and FFA amounted to $2.76 \%$. Analysis of fatty acid composition of avocado seed oil showed fatty acid component is predominantly polyunsaturated fatty acids as linoleic acid of $47.3531 \%(\mathrm{w} / \mathrm{w})$, saturated fatty acids such as palmitic acid amounted to $20.3439 \%(w / w)$, and monounsaturated fatty acids as oleic acid amounted to $15.8823 \%(w / w)$.
\end{abstract}

Keywords : avocado, avocado seed oil, extraction, heptane, linoleic acid

\section{Pendahuluan}

Hampir semua orang mengenal dan menyukai buah alpukat karena buah ini mudah didapat dan rasanya lezat khususnya di Indonesia. Namun, kebanyakan orang hanya memakan daging buahnya saja, sedangkan biji alpukat dibuang dan menjadi limbah begitu saja. Produksi alpukat di Indonesia cukup tinggi, hal ini dapat dibuktikan dengan data produksi buah alpukat di Indonesia pada tahun 2014 dari Badan Pusat Statistik (BPS) yaitu mencapai 307.326 ton per tahun. Dari data BPS, produksi alpukat di Indonesia terus meningkat setiap tahunnya [2], seiring dengan meningkatnya produksi alpukat, maka limbah biji alpukat yang dihasilkan juga meningkat. Oleh karena itu, perlu penanganan terhadap limbah biji alpukat dengan dilakukan penelitian mengenai biji alpukat.

Biji alpukat terdiri dari $65 \%$ daging buah (mesokarp), 20\% biji (endocarp), dan 15\% kulit buah (perikarp). Menurut Prasetyowati, biji alpukat mengandung $15-20 \%$ minyak [15]. Biji alpukat mengandung minyak yang hampir sama dengan kedelai sehingga biji alpukat dapat dijadikan sebagai sumber minyak nabati [3]. Minyak biji alpukat dapat diperoleh dengan metode ekstraksi maupun metode pengepresan. Metode ekstraksi menyebabkan kehilangan minyak dalam proses lebih sedikit, sehingga minyak yang dihasilkan lebih banyak [15]. 
Ekstraksi dengan pelarut merupakan metode yang paling banyak digunakan untuk mengekstrak minyak dari hasil pertanian. Heksana merupakan pelarut yang paling banyak digunakan untuk proses ekstraksi [14]. Namun EPA (Environmental Protection Agency) menyatakan bahwa meskipun heksana telah umum digunakan sebagai pelarut ekstraksi minyak nabati dari biji dan sayuran, heksana menyebabkan toksisitas jangka pendek dan panjang seperti pusing, sakit kepala, dan efek neurotoksik [9]. Dalam banyak aplikasi (terutama farmasi), kegunaan n-heksana juga dihapus dan sering digantikan oleh n-heptana, yang tidak akan membentuk metabolit beracun (heksana-2,5-dion) [10]. Ayers dan Dooley [1] mengekstraksi biji kapas pada skala laboratorium dengan berbagi macam pelarut termasuk pelarut heksana dan heptana. Jumlah minyak yang di ekstraksi oleh kedua pelarut tersebut sama, tetapi kehilangan akibat refining dan warna minyak bervariasi. Mereka juga mencatat bahwa perbedaan warna minyak tergantung pada kandungan asam lemak bebas (FFA) dari bji. Secara umum minyak yang diekstraksi dengan heksana memiliki warna yang lebih tajam dibanding dengan heptana dan juga fosfolipid yang diekstraksi dengan heptana lebih tinggi dibanding dengan heksana [8].

Penelitian ini bertujuan untuk mengkaji pengaruh waktu ekstraksi, suhu ekstraksi dan perbandingan massa biji alpukat dengan pelarut nheptana terhadap ekstrak minyak biji alpukat serta Menentukan karakteristik minyak biji alpukat hasil ekstraksi dengan pelarut n-heptana.

\section{Teori}

Tanaman alpukat berasal dari Amerika tengah yang beriklim tropis dan telah menyebar hampir ke seluruh negara sub-tropis dan tropis termasuk indonesia. Di samping daging buahnya, biji alpukat juga memiliki potensi karena proteinnya tinggi bahkan alpukat memiliki kandungan minyak yang cukup tinggi sehingga biji alpukat dapat dijadikan sebagai sumber minyak nabati [15].

Klasifikasi lengkap tanaman alpukat adalah sebagai berikut [11]:

$\begin{array}{ll}\text { Divisi } & \text { : Spermatophyta } \\ \text { Anak divisi } & \text { : Angiospermae } \\ \text { Kelas } & \text { : Dicotyledoneae } \\ \text { Bangsa } & \text { : Ranales } \\ \text { Keluarga } & \text { : Lauraceae } \\ \text { Marga } & \text { : Persea } \\ \text { Varietas } & \text { : Persea americana Mill }\end{array}$

Menurut Rachimoellah pada penelitiannya mengenai produksi biodiesel dari minyak biji alpukat, terdapat kandungan minyak sebesar $15 \%$ [16]. Hasil penelitian Prasetyowati, dkk., 2010 juga menyatakan biji alpukat mengandung minyak $15-20 \%$ [15]. Menggunakan pelarut n-heksana dengan variasi massa biji alpukat (30 dan 50 gram), volume pelarut $(200,300,400 \mathrm{ml})$, dan waktu ekstraksi (60, 90, 120 menit) dihasilkan yield minyak biji alpukat berkisar antara 16,62 - 25,15\% [15]. Penelitian Pramudono, dkk, 2008 menggunakan variasi pelarut n-heksana dan iso propil alkohol dengan rasio massa terhadap pelarut 20/250 gram dan waktu ekstraksi 2 jam menghasilkan yield minyak biji alpukat 18,69 dan $17,87 \%$ [3].

Ekstraksi adalah proses pemisahan satu atau lebih komponen dari suatu campuran homogen menggunakan pelarut cair (solvent) sebagai separating agent. Dengan kata lain terjadi pemisahan fisika berdasarkan prinsip beda konsentrasi dan beda kelarutan. Hasil yang didapatkan kemudian dipisahkan menjadi dua bagian yaitu ekstrak dan rafinat. Ekstrak tersebut mengandung solut dan pelarut sedangkan rafinat mengandung inert, sisa pelarut dan sisa solut. Sokhlet merupakan proses pemisahan berulang dengan sampel berupa padatan. Sampel yang akan diekstrak biasanya padatan yang telah dihaluskan. Padatan ini lalu dibungkus dengan kertas saring lalu dimasukkan dalam alat sokhlet. Alat ini pada bagian atas dihubungkan dengan pendingin balik sedangkan bagian bawah terdapat labu alas bulat sebagai tempat pelarut. Pemanasan dengan suhu tertentu akan menguapkan pelarut. Uap akan naik ke atas mengalami proses pendinginan. Ruang sokhlet akan dipenuhi oleh pelarut yang telah mengembun hingga batas tertentu pelarut tersebut akan membawa solut dalam labu. Proses ini berlangsung terus menerus. Keuntungan metode ini adalah ekstraksi berlangsung cepat, cairan pengekstraksi yang dibutuhkan sedikit, dan cairan pengekstraksi tidak pernah mengalami kejenuhan [7]. Adapun rangkaian peralatan sokhlet dapat dilihat pada gambar 1 .

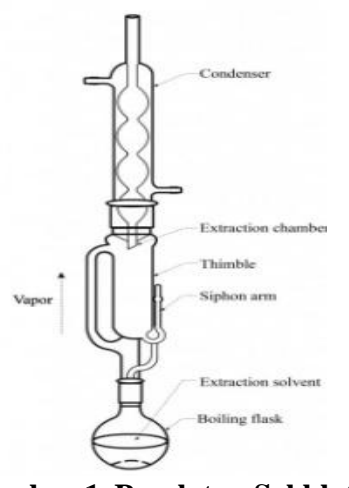

Gambar 1. Peralatan Sokhlet

Ada beberapa faktor yang dapat mempengaruhi efisiensi ekstraksi, diantaranya metode ekstraksi, jenis dan konsentrasi pelarut, ukuran parttikel dari bahan yang akan diekstraksi, 
waktu ekstraksi, suhu ekstraksi, rasio pelarut terhadap bahan, dan $\mathrm{pH}$ ekstraksi [6].

Metode permukaan respon (response surface methodology) merupakan sekumpulan teknik matematika dan statistika yang berguna untuk menganalisis permasalahan dimana beberapa variabel independen mempengaruhi variabel respon dan tujuan akhirnya adalah untuk mengoptimalkan respon. Ide dasar metode ini adalah memanfaatkan desain eksperimen berbantuan statistika untuk mencari nilai optimal dari suatu respon [13].

Level-level eksperimen pada masing-masing variabel independen dikodekan sedemikian hingga level rendah berhubungan dengan -1 dan level tinggi berhubungan dengan 1 untuk mempermudah perhitungan. Desain Central Composite Design (CCD) pada eksperimen yang menggunakan tiga variabel independen nilai rotatabilitasnya $=\left(2^{3}\right)^{1 / 4}$ $=1,6818 \approx 1,682$. Oleh karena itu, nilai $\pm 1,682$ termasuk nilai yang digunakan untuk pengkodean [13].

Adapun level kode dan kombinasi perlakuan penelitian dapat dilihat pada tabel 1 .

Tabel 1. Level Kode Rancangan Penelitian

\begin{tabular}{|c|c|c|c|c|c|c|c|}
\hline \multirow{2}{*}{ Variabel } & \multirow{2}{*}{ Satuan } & \multirow{2}{*}{ Kode } & \multicolumn{5}{|c|}{ Level dan Range } \\
\hline & & & $-1,682$ & -1 & 0 & +1 & $+1,682$ \\
\hline \multicolumn{8}{|c|}{$\mathrm{T}=98,4^{\circ} \mathrm{C}$} \\
\hline $\begin{array}{c}\text { Waktu } \\
\text { ekstraksi }\end{array}$ & menit & $\mathrm{t}$ & 69,5 & 90 & 120 & 150 & 170,5 \\
\hline $\begin{array}{c}\text { Massa biji } \\
\text { alpukat }\end{array}$ & gram & W & 13,2 & 20 & 30 & 40 & 46,8 \\
\hline $\begin{array}{c}\text { Volume } \\
\text { pelarut n- } \\
\text { heptana }\end{array}$ & $\mathrm{ml}$ & V & 215,9 & 250 & 300 & 350 & 384,1 \\
\hline \multicolumn{8}{|c|}{$t=180$ menit } \\
\hline $\begin{array}{c}\text { Suhu } \\
\text { ekstraksi }\end{array}$ & ${ }^{\circ} \mathrm{C}$ & $\mathrm{T}$ & 81,6 & 85 & 90 & 95 & 98,4 \\
\hline $\begin{array}{c}\text { Massa biji } \\
\text { alpukat }\end{array}$ & gram & W & 13,2 & 20 & 30 & 40 & 46,8 \\
\hline $\begin{array}{c}\text { Volume } \\
\text { pelarut n- } \\
\text { heptana }\end{array}$ & $\mathrm{ml}$ & V & 215,9 & 250 & 300 & 350 & 384,1 \\
\hline
\end{tabular}

\section{Metodologi Penelitian}

Bahan dan Alat

Bahan yang digunakan adalah biji alpukat dan pelarut $n$-heptana. Alat utama yang digunakan adalah rangkaian peralatan sokhlet dan distilasi, piknometer, dan viskosimeter.

\section{Persiapan Bahan Baku}

Biji alpukat yang telah dikumpulkan dikupas kulit arinya. Kemudian dicuci dan dibersihkan dengan air. Lalu dipotong-potong untuk dikeringkan. Selanjutnya, dihaluskan dengan menggunakan blender. Dikeringkan dengan menggunakan oven dengan suhu $\pm 100{ }^{\circ} \mathrm{C}$ dan kemudian diayak dengan ayakan 50 mesh. Sehingga diperoleh bubuk biji alpukat.

\section{Ekstraksi Minyak dari Biji Alpukat}

Peralatan ekstraksi berupa labu, refluks kondensor, sokhlet, termometer dan hot plate dirangkai. Biji alpukat yang telah dihancurkan, dihaluskan, dikeringkan dan diayak diumpankan ke dalam ekstraktor kemudian diikuti dengan penambahan pelarut $n$-heptana dengan rasio sesuai rancangan penelitian. Dipanaskan hingga suhu titik didihnya dan dihitung waktu ekstraksi sesuai rancangan penelitian. Diperoleh ekstrak berupa campuran minyak biji alpukat dan pelarut nheptana. Kemudian dilakukan distilasi untuk memisahkan pelarut n-heptana dan diperoleh ekstrak minyak biji alpukat.

\section{Analisis Minyak Biji Alpukat}

Analisis yang dilakukan diantaranya analisis densitas, viskositas, \% FFA, dan komposisi asam lemak minyak biji alpukat menggunakan GC (Gas Chromatography).

\section{Hasil dan Pembahasan}

Minyak biji alpukat yang telah dipisahkan dari pelarut n-heptana, ditimbang beratnya dan diukur volumenya. Dari berat minyak biji alpukat yang diperoleh, dihitung yield minyak biji alpukat, dengan cara sebagai berikut:

$$
\text { Yield }(\%)=\frac{\text { massa minyak biji alpukat }}{\text { massa biji alpukat }} \times 100 \%
$$

Dari tabel 2 dan 3 dapat dilihat bahwa yield (\%) minyak yang dihasilkan mengalami fluktuasi. Dengan menggunakan analisis regresi dan analisis varians (ANOVA) dapat dilihat diantara keempat variabel tersebut, variabel yang paling berpengaruh terhadap yield minyak biji alpukat.

Tabel 2. Yield (\%) Minyak Biji Alpukat Hasil

\begin{tabular}{|c|c|c|c|c|}
\multicolumn{5}{|c|}{ Ekstraksi } \\
\hline No & $\begin{array}{c}\left.\mathrm{T}=98, \mathbf{4}^{\mathbf{0}} \mathbf{C}\right) \\
(\text { menit) }\end{array}$ & $\begin{array}{c}\mathrm{W} \\
(\mathrm{gr})\end{array}$ & $\begin{array}{c}\mathrm{V} \\
(\mathrm{ml})\end{array}$ & $\begin{array}{c}\text { Yield } \\
(\%)\end{array}$ \\
\hline 1 & 120 & 30 & 215,9 & 16,33 \\
2 & 120 & 13,2 & 300 & 15,40 \\
3 & 90 & 20 & 250 & 15,00 \\
4 & 90 & 20 & 350 & 6,55 \\
5 & 120 & 30 & 300 & 22,67 \\
6 & 90 & 40 & 250 & 6,55 \\
7 & 150 & 40 & 350 & 8,75 \\
8 & 69,5 & 30 & 300 & 8,00 \\
9 & 170,5 & 30 & 300 & 18,00 \\
10 & 120 & 30 & 300 & 22,67 \\
11 & 150 & 20 & 250 & 34,00 \\
12 & 90 & 40 & 350 & 4,35 \\
13 & 120 & 46,8 & 300 & 7,90 \\
14 & 150 & 40 & 250 & 15,70 \\
15 & 120 & 30 & 300 & 22,67 \\
16 & 120 & 30 & 384,1 & 7,00 \\
17 & 150 & 20 & 350 & 18,70 \\
18 & 120 & 30 & 300 & 22,67 \\
19 & 120 & 30 & 300 & 22,67 \\
20 & 120 & 30 & 300 & 22,67 \\
\hline
\end{tabular}


Tabel 3. Yield (\%) Minyak Biji Alpukat Hasil

\begin{tabular}{|c|c|c|c|c|}
\hline \multicolumn{5}{c}{ Ekstraksi (t=180 menit) } \\
\hline No & $\begin{array}{c}\text { T } \\
\left({ }^{\circ} \mathrm{C}\right)\end{array}$ & $\begin{array}{c}\text { W } \\
(\mathrm{gr})\end{array}$ & $\begin{array}{c}\text { V } \\
(\mathrm{ml})\end{array}$ & $\begin{array}{c}\text { Yield } \\
(\%)\end{array}$ \\
\hline 1 & 85 & 20 & 250 & 7,00 \\
2 & 85 & 40 & 350 & 8,00 \\
3 & 95 & 20 & 350 & 18,45 \\
4 & 95 & 40 & 250 & 13,78 \\
5 & 90 & 30 & 300 & 18,00 \\
6 & 85 & 20 & 350 & 14,05 \\
7 & 85 & 40 & 250 & 8,50 \\
8 & 95 & 20 & 250 & 24,00 \\
9 & 95 & 40 & 350 & 7,25 \\
10 & 90 & 30 & 300 & 18,00 \\
11 & 81,6 & 30 & 300 & 12,33 \\
12 & 98,4 & 30 & 300 & 19,33 \\
13 & 90 & 13,2 & 300 & 15,17 \\
14 & 90 & 46,8 & 300 & 8,76 \\
15 & 90 & 30 & 215,9 & 17,33 \\
16 & 90 & 30 & 384,1 & 15,00 \\
17 & 90 & 30 & 300 & 18,00 \\
18 & 90 & 30 & 300 & 18,00 \\
19 & 90 & 30 & 300 & 18,00 \\
20 & 90 & 30 & 300 & 18,00 \\
\hline
\end{tabular}

Model Regresi dan Analisis Varians (ANOVA)

Menggunakan software Minitab 16, data percobaan yang diperoleh dianalisis dengan statistik.

Berdasarkan hasil analisis regresi pada tabel 4 , diperoleh hubungan \% yield dengan ketiga variabel yaitu sebagai berikut :

Yield $(\%)\left(\mathrm{T}=98,4^{\circ} \mathrm{C}\right)=22,598+4,505 \mathrm{t}-3,772 \mathrm{~W}$ $-3,558 \mathrm{~V}-2,947 \mathrm{t}^{2}-3,424 \mathrm{~W}^{2}-3,419 \mathrm{~V}^{2}-2,2 \mathrm{tW}$ $-1,45 \mathrm{tV}+1,825 \mathrm{WV}$

Yield $(\%)(\mathrm{t}=180$ menit $)=18,0599+2,7622 \mathrm{~T}-$ $2,6925 \mathrm{~W}-0,6918 \mathrm{~V}-1,1534 \mathrm{~T}^{2}-2,5228 \mathrm{~W}^{2}$ $1,0314 \mathrm{~V}^{2}-2,1087 \mathrm{TW}-2,3287 \mathrm{TV}-1,0662 \mathrm{WV}$

Dimana t, T, W dan V merupakan waktu ekstraksi, suhu ekstraksi, massa biji alpukat dan volume pelarut. Untuk menguji kecocokan dari model, koefisien determinasi $\left(\mathrm{R}^{2}\right)$ dievaluasi. Pada tabel 5 ditunjukkan nilai $\mathrm{R}^{2}$ sebesar $94,24 \%$ $\left(\mathrm{T}=98,4^{\circ} \mathrm{C}\right) \quad$ dan $93,95 \% \quad(\mathrm{t}=180 \quad$ menit $)$, ini menunjukkan validitas untuk variabel terikat. Dari nilai koefisien determinasi tersebut juga dapat diartikan bahwa model ini dapat menjelaskan $94,24 \%$ dan 93,95\% dari variabilitas. Interaksi antara waktu dan massa, suhu dan massa serta suhu dan volume memberikan hasil yang signifikan karena memiliki nilai $\mathrm{p}$ kecil dari $\alpha=$ $0,05(\mathrm{p}<0,05)$. Artinya, interaksi variabel tersebut sangat berpengaruh dalam ekstraksi minyak dari biji alpukat.

Tabel 5 menunjukkan hasil analisis varians (ANOVA) untuk variabel penelitian terhadap model orde-kedua yaitu persentase yield. Dari tabel tersebut, diperoleh $\mathrm{F}_{\text {hitung }}(18,17$ dan 17,26) dan $F_{\text {tabel }}\left(F_{0,95 ; 9 ; 10}=3,02\right)$. Jika $F_{\text {hitung }}>F_{\text {tabel }}$ maka disimpulkan nilai regresi signifikan [4]. Pada hasil analisis di atas diperoleh nilai $F_{\text {hitung }}>F_{\text {tabel }}$, sehingga regresi dapat dinyatakan signifikan.
Tabel 4. Perkiraan Model Persamaan Statistik

\begin{tabular}{|c|c|c|c|c|}
\hline Term & Coef & SE Coef & $T$ & $\mathbf{P}$ \\
\hline \multicolumn{5}{|c|}{$\mathrm{T}=98,4^{\circ} \mathrm{C}$} \\
\hline Constant & 22,598 & 1,0641 & 21,236 & 0,000 \\
\hline $\mathrm{t}$ & 4,505 & 0,7060 & 6,380 & 0,000 \\
\hline $\mathrm{W}$ & $-3,772$ & 0,7060 & $-5,343$ & 0,000 \\
\hline V & $-3,558$ & 0,7060 & $-5,040$ & 0,001 \\
\hline$t^{*} t$ & $-2,947$ & 0,6873 & $-4,288$ & 0,002 \\
\hline $\mathrm{W} * \mathrm{~W}$ & $-3,424$ & 0,6873 & $-4,982$ & 0,001 \\
\hline $\mathrm{V} * \mathrm{~V}$ & $-3,419$ & 0,6873 & $-4,975$ & 0,001 \\
\hline$t^{*} W$ & $-2,200$ & 0,9225 & $-2,385$ & 0,038 \\
\hline$t^{*} \mathrm{~V}$ & $-1,450$ & 0,9225 & $-1,572$ & 0,147 \\
\hline $\mathrm{W} * \mathrm{~V}$ & 1,825 & 0,9225 & 1,978 & 0,076 \\
\hline \multicolumn{5}{|c|}{$t=180$ menit } \\
\hline Constant & 18,0559 & 0,6610 & 27,321 & 0,000 \\
\hline $\mathrm{T}$ & 2,7622 & 0,4388 & 6,295 & 0,000 \\
\hline W & $-2,6925$ & 0,4388 & $-6,136$ & 0,000 \\
\hline V & $-0,6918$ & 0,4386 & $-1,577$ & 0,146 \\
\hline $\mathrm{T}^{*} \mathrm{~T}$ & $-1,1534$ & 0,4277 & $-2,697$ & 0,022 \\
\hline $\mathrm{W}^{*} \mathrm{~W}$ & $-2,5228$ & 0,4277 & $-5,899$ & 0,000 \\
\hline $\mathrm{V} * \mathrm{~V}$ & $-1,0314$ & 0,4268 & $-2,416$ & 0,036 \\
\hline $\mathrm{T} * \mathrm{~W}$ & $-2,1087$ & 0,5731 & $-3,680$ & 0,004 \\
\hline $\mathrm{T} * \mathrm{~V}$ & $-2,3287$ & 0,5731 & $-4,064$ & 0,002 \\
\hline $\mathrm{W} * \mathrm{~V}$ & $-1,0662$ & 0,5731 & $-1,861$ & 0,092 \\
\hline
\end{tabular}

Tabel 5. Analysis of Variance Terhadap Yield

\begin{tabular}{|c|c|c|c|c|c|}
\hline $\begin{array}{l}\text { Sumber } \\
\text { Variasi }\end{array}$ & Df & SS & MS & $\mathbf{F}_{\text {hitung }}$ & $\mathbf{F}_{\text {tabel }}$ \\
\hline \multicolumn{6}{|c|}{$\mathrm{T}=98,4^{\circ} \mathrm{C}$} \\
\hline Regresi & 9 & 1113,05 & & 18,17 & \multirow[t]{3}{*}{3,02} \\
\hline Residual Error & 10 & 68,07 & \multirow{2}{*}{6,807} & & \\
\hline Total & 19 & 1181,13 & & & \\
\hline \multicolumn{6}{|c|}{$\mathrm{R}-\mathrm{Sq}=94,24 \%$} \\
\hline \multicolumn{6}{|c|}{$t=180$ menit } \\
\hline Regresi & 9 & 408,142 & 45,349 & \multirow[t]{3}{*}{17,26} & \multirow[t]{3}{*}{3,02} \\
\hline Residual Error & 10 & 26,272 & 2,627 & & \\
\hline Total & 19 & 434,414 & & & \\
\hline \multicolumn{6}{|c|}{$\mathrm{R}-\mathrm{Sq}=93,95 \%$} \\
\hline
\end{tabular}

\section{Sifat Fisika dan Kimia Minyak Biji Alpukat}

Analisis yang dilakukan diantaranya, analisis densitas, viskositas, dan Free Fatty Acid (FFA). Hasil analisis minyak yang diperoleh pada suhu ekstraksi $98,4^{\circ} \mathrm{C}$ selama 120 menit dengan massa biji 30 gram dan volume pelarut $300 \mathrm{ml}$ ditunjukkan pada tabel 6 .

Tabel 6. Sifat Fisika dan Kimia Minyak Biji Alpukat

\begin{tabular}{|l|c|}
\hline \multicolumn{1}{|c|}{ Sifat Fisika dan Kimia } & Hasil \\
\hline Warna pada $30{ }^{\circ} \mathrm{C}$ & Oranye \\
Densitas pada $20{ }^{\circ} \mathrm{C}(\mathrm{g} / \mathrm{ml})$ & 0,71 \\
Viskositas pada $40{ }^{\circ} \mathrm{C}(\mathrm{cP})$ & 0,43 \\
$\%$ FFA & 2,76 \\
\hline
\end{tabular}

Prasetyowati [15] melakukan ekstraksi minyak biji alpukat menggunakan pelarut nheksana, diperoleh densitas sebesar 0,6951-0,7676 $\mathrm{gr} / \mathrm{ml}$; viskositas sebesar 0,826-4,55 cSt dan \% FFA sebesar 7,027-9,283\%. Densitas dari minyak biji alpukat dengan n-heptana masih berada dalam rentang densitas yang telah dilaporkan. Sedangkan viskositas yang dihasilkan (konversi cP ke cSt) sebesar 0,606 cSt berada dibawah rentang viskositas yang telah dilaporkan. Ketika panas diberikan pada cairan, molekul-molekul kemudian dapat bergerak bebas dengan mudah yang mengakibatkan viskositas cairan berkurang [4]. Suhu ekstraksi dengan pelarut n-heptana lebih tinggi dibanding dengan n-heksana sehingga 
viskositas minyak yang dihasilkan lebih rendah. Kemudian untuk \% FFA yang dihasilkan, lebih rendah dibanding dengan menggunakan n-heksana. Perbedaan kuantitatif ini dapat disebabkan karena perbedaan geografi tempat asal tumbuhan dan faktor lain seperti kematangan dan proses pemanenan [5]. Belakangan telah banyak dilakukan penelitian mengenai penggunaan minyak biji alpukat sebagai bahan baku biodiesel. Jika akan digunakan sebagai bahan baku pembuatan biodiesel dengan \% FFA besar dari $2 \%$, minyak biji alpukat memerlukan proses esterifikasi terlebih dahulu untuk mengubah FFA menjadi metil ester sehingga minyak dapat diproses dengan transesterifikasi.

\section{Komposisi Asam Lemak Minyak Biji Alpukat}

Komposisi asam lemak dari minyak biji alpukat yang diperoleh pada suhu ekstraksi $98,4^{\circ} \mathrm{C}$ selama 120 menit dengan massa biji 30 gram dan volume pelarut $300 \mathrm{ml}$ dianalisis dengan menggunakan instrumentasi Gas Chromatography (GC).

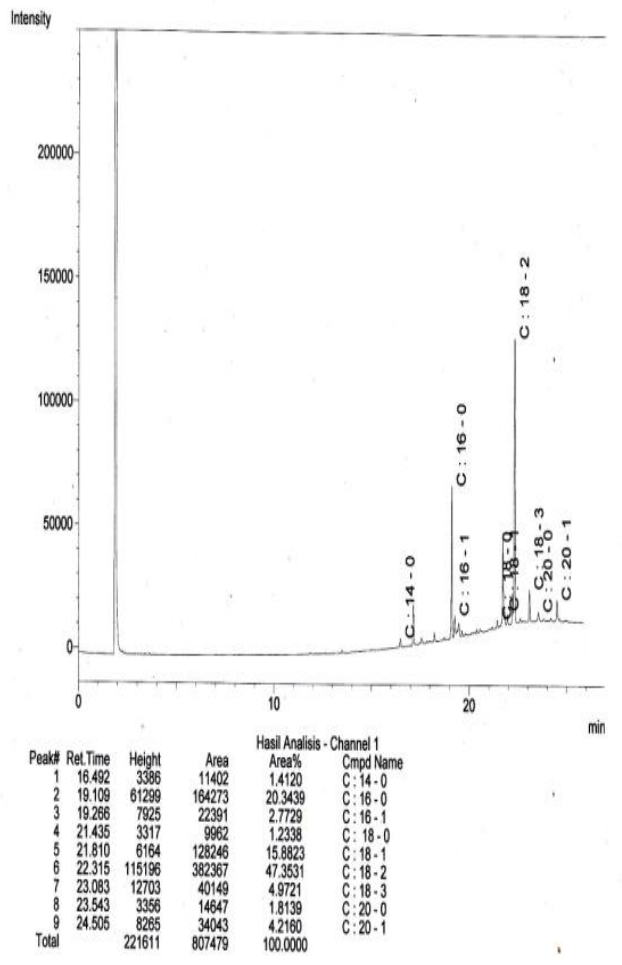

Gambar 2. Hasil Analisis Komposisi Asam Lemak Minyak Biji Alpukat

Dari gambar 2, data komposisi asam lemak disajikan kembali pada tabel 7, maka dapat ditentukan berat molekul FFA minyak biji alpukat adalah 276,224 gr/mol. Dapat dilihat bahwa komponen asam lemak yang dominan adalah asam lemak tidak jenuh jamak yaitu asam linoleat sebesar 47,3531\% (b/b), asam lemak jenuh berupa asam palmitat sebesar $20,3439 \%$ (b/b), dan asam lemak tidak jenuh tunggal yaitu asam oleat sebesar $15,8823 \%(\mathrm{~b} / \mathrm{b})$.

Tabel 7. Komposisi Asam Lemak Minyak Biji Alpukat

\begin{tabular}{|l|c|}
\hline Asam Lemak & Komposisi \\
\hline Asam Miristat (14:0) & 1,4120 \\
Asam Palmitat (16:0) & 20,3439 \\
Asam Palmitoleat (16:1) & 2,7729 \\
Asam Stearat (18:0) & 1,2328 \\
Asam Oleat (18:1) & 15,8823 \\
Asam Linoleat (18:2) & 47,3531 \\
Asam Linolenat (18:3) & 4,9721 \\
Asam Arachidat (20:0) & 1,8139 \\
Asam Gadoleat (20:1) & 4,2160 \\
\hline Total & 100,0000 \\
\hline
\end{tabular}

Tabel 8. Rasio Asam Lemak Minyak Biji Alpukat

\begin{tabular}{|l|c|}
\hline \multicolumn{1}{|c|}{ Asam Lemak } & Rasio \\
\hline Asam Lemak Tak Jenuh/Jenuh & 3,03 \\
Asam Lemak Tak Jenuh Jamak/Jenuh & 2,11 \\
Asam Oleat/Linoleat & 0,34 \\
Asam linoleat/Linolenat & 9,52 \\
\hline
\end{tabular}

Tabel 8 menunjukkan rasio asam lemak dari minyak biji alpukat. Rasio antara asam lemak tak jenuh terhadap asam lemak jenuh adalah 3,03 dan rasio antara asam lemak tak jenuh jamak terhadap asam lemak jenuh adalah 2,11. Bora menyajikan rasio yang lebih rendah yaitu 2,07 dan 1,44 [5]. Dalam hubungan rasio asam oleat terhadap asam linoleat dinyatakan sebuah parameter yang berperan dalam umur penyimpanan minyak [5]. Rasio asam oleat terhadap asam linoleat pada penelitian ini yaitu 0,34 . Sedangkan rasio asam linoleat dengan asam linolenat (C18:2/C18:3) diperoleh sebesar 9,52 yang lebih tinggi dibandingkan dengan perolehan Bora [15] dan Galvao [12] berturut-turut yaitu 5,92 dan 2,95. Bora et.al, 2001 menyatakan bahwa rasio antara asam linoleat dan linolenat yang tinggi dapat berperan dalam menurunkan trigliserida dan HDL dalam plasma darah [5]. Oleh karena itu, minyak biji alpukat yang dihasilkan cukup berkhasiat untuk kesehatan.

\section{Kesimpulan}

Berdasarkan analisis regresi dan ANOVA, suhu dan waktu merupakan faktor yang paling signifikan berpengaruh terhadap ekstraksi minyak dari biji alpukat dengan pelarut n-heptana. Hasil analisis komposisi asam lemak minyak biji alpukat menunjukkan bahwa minyak didominasi oleh asam linoleat, asam oleat, dan asam palmitat. Minyak biji alpukat yang dihasilkan cukup berkhasiat untuk kesehatan seperti dapat menurunkan kolesterol dalam darah. Meskipun masih diperlukan pengujian lebih lanjut mengenai toksisitas dan kandungan di dalam minyak tersebut. 


\section{DAFTAR PUSTAKA}

[1] Ayers, A.L., J.J. Dooley,"Extraction Solvents for Cottonseed : A Laboratory-Scale Study", Journal AOCS, Vol. 25, 1948.

[2] Badan Pusat Statistik, "Survey Pertanian Produksi Buah-buahan di Indonesia," Biro Pusat Statistik, Jakarta, 2013.

[3] Bambang Pramudono, Septian Ardi Widioko, Wawan Rustyawan, "Ekstraksi Kontinyu dengan Simulasi Batch Tiga Tahap Aliran Lawan Arah: Pengambilan Minyak Biji Alpukat Menggunakan Pelarut n-Hexane dan Iso Propil Alkohol," Jurnal Reaktor, Vol. 12 No. 1, Juni 2008.

[4] Bernat Esteban, Jordi-Roger Riba, Grau Baquero, Antoni Rius, Rita Puig, "Temperature Dependence Of Density and Viscosity Of Vegetable Oils." Biomass and Bioenergy, 42, 2012.

[5] Bora, Pushkar S., Narain, Narendra, et. al., "Characterization of the Oils from The Pulp and The Seed of Avocado," Grasas y Aceites Vol. 52, Fasc. 3-4, 2001.

[6] Chew, K.K., Khoo, M.Z., et. al,'Effect of Ethanol Concentration, Extraction Time, and Entraction Temperature on the Recovery of Phenolic Compounds and Antioxidant Capacity of Orthosiphon stamineus Extracts", International Food Research Journal 18(4), 2011.

[7] Dyah Septyaningsih, "Isolasi dan Identifikasi Komponen Utama Ekstrak Biji Buah Merah (Pandanus conoideus Lamk.)." Skripsi, Program Sarjana Fakultas Matematika dan Ilmu Pengetahuan Alam Universitas Sebelas Maret, Surakarta, 2010.

[8] E.J. Conkerton, P.J. Wan, O.A. Richard, "Hexane and Heptane as Extraction Solvents for Cottonseed: A Laboratory-Scale Study," JAOCS, Vol. 72, No. 8, 1995.

[9] EPA, Hexane, United States Environmental Protection Agency, 2013.

[10] McCann, Michael, Health Hazards of Solvents, University of Illinois at Chicago, 1994.

[11] Menegristek, "Alpukat / Avokad (Persea americana Mill/Persea gratissima Gaerth)," Menegristek Bidang Pendayagunaan dan Pemasyarakatan Ilmu Pengetahuan dan Teknologi, Jakarta, 2000.

[12] Mercia de Sousa Galvao, Narendra Narain, Nisha Nigam, "Influence of Different Cultivars on Oil Quality and Chemical Characteristics of Avocado Fruit." Food and Science Technology, 34(3), 2014.

[13] Nuryanti, Salimi, Djati H.,'Metode Permukaan Respond an Aplikasinya pada Optimasi Eksperimen Kimia”, Risalah Lokakarya Komputasi dalam Sains dan Teknologi Nuklir, 2008.

[14] Orhevba, B.A, Jinadu, A.O, "Determination of Physico-Chemical Properties and Nutritional Contents of Avocado Pear (Persea Americana M.)," SAVAP International Journal Volume 1, Issue 3, 2011.

[15] Prasetyowati, Retno Pratiwi, Fera Tris O, "Pengambilan Minyak Biji Alpukat (Persea Americana Mill) dengan Metode Ekstraksi," Jurnal Teknik Kimia, No. 2, Vol. 17, April 2010.

[16] Rachimoellah, H.M., Resti, Dyah Ayu., Zibbeni, et. al., "Production of Biodiesel through Transesterification of Avocado (Persea Gratissima) Seed Oil Using Base Catalyst," Jurnal Teknik Mesin, Vol. 11, No. 2, 2009. 